\title{
Dual Antiplatelet Therapy for Coronary Artery Disease
}

\author{
Cheol Whan Lee, MD
}

\begin{abstract}
Platelets initiate the formation of a thrombus at the site of an arterial injury, and the clotting cascade is activated as the thrombus matures. After coronary stent placement, dual antiplatelet therapy (DAPT) with aspirin and ticlopidine dramatically reduces the risk of stent thrombosis, compared with anticoagulation therapy, and has become the standard of care for prevention of stent thrombosis. Clopidogrel is a second-generation thienopyridine that eliminates the serious side effects of ticlopidine, and new $\mathrm{P}_{2} \mathrm{Y}_{12}$ receptor blockers have emerged to overcome the limitations of clopidogrel. Current guidelines recommend DAPT with aspirin and clopidogrel for 1 month after implantation of bare-metal stents, and for 6-12 months after implantation of drug-eluting stents (DES). In patients with acute coronary syndrome (ACS), DAPT administration for 12 months was shown to be superior to aspirin alone for the prevention of recurrent events. Treatment with aspirin and new $\mathrm{P}_{2} \mathrm{Y}_{12}$ receptor blockers has further reduced the rate of cardiovascular death, myocardial infarction or stroke after ACS compared with aspirin and clopidogrel. Nonetheless, long-term DAPT increases the risk of major bleeding, requiring a delicate balance between anti-ischemic benefit and bleeding risk. In summary, DAPT should be maintained for at least 6-12 months after implantation of DES, and for at least 12 months after ACS, unless contraindicated. (Circ $J$ 2015; 79: 255-262)
\end{abstract}

Key Words: Acute coronary syndrome; Antiplatelet therapy; Drug-eluting stents

A spirin prevents serious vascular events in patients at high risk of atherosclerosis. ${ }^{1,2}$ The mechanism of aspirin's antiplatelet action was first described in $1971,{ }^{3}$ but it took a long time before aspirin's value was accepted in cardiovascular medicine. Early aspirin trials were mostly of questionable statistical significance. Moreover, the first large randomized trial, the Aspirin Myocardial Infarction Study (AMIS), showed that aspirin (1,000 mg/day) did not prevent cardiac death in patients who had already had a myocardial infarction (MI). ${ }^{4}$ Adverse side effects, including peptic ulcer and gastrointestinal bleeding, were higher in the aspirin group than in the placebo group. Based on the AMIS results, aspirin was not routinely recommended for patients who had survived a MI. In the large, randomized International Study of Infarct Survival (ISIS)-2, however, aspirin ( $160 \mathrm{mg}$ /day) demonstrated a dramatic $23 \%$ reduction in vascular mortality compared with placebo in patients with acute MI. ${ }^{5}$ Thereafter, the use of aspirin in real-world clinical practice rapidly increased in advance of controlled studies, reflecting the ISIS-2 trial's strong positive results. ${ }^{6}$ Furthermore, in most clinical studies, aspirin has become the default therapy for arterial thrombosis. Current guidelines recommend the use of low-dose aspirin (75$325 \mathrm{mg} /$ day) indefinitely for patients with established atherosclerotic cardiovascular disease. ${ }^{7}$

\section{P2Y 12 Receptor Blockers}

\section{Evolution of P2Y 12 Receptor Blockers}

Platelets are critical during the initial development of arterial thrombi, and are activated when the vascular endothelium is damaged. Platelet activation can be triggered by many different agonists, including adenosine diphosphate, thromboxane $\mathrm{A}_{2}$, thrombin, etc. Adenosine diphosphate, as a $\mathrm{P}_{2} \mathrm{Y}_{12}$ receptor agonist, induces platelet degranulation and shape change, leading to amplification and stabilization of platelet aggregation. ${ }^{8}$ The central role of the $\mathrm{P} 2 \mathrm{Y}_{12}$ receptor in platelet activation has made it a key target of antiplatelet agents. Ticlopidine, a firstgeneration thienopyridine, was discovered in 1972 and introduced as an antiplatelet agent in 1978. Despite its excellent antiplatelet effect, ticlopidine has rare but potentially fatal side effects, including aplastic anemia, neutropenia and thrombotic thrombocytopenic purpura, requiring routine hematological monitoring. ${ }^{9}$ Clopidogrel is a second-generation thienopyridine lacking the serious hematological side effects of ticlopidine and was approved for use in 1997. Clopidogrel has quickly replaced ticlopidine because of its equivalent efficacy and superior safety profile. $\mathrm{P}_{2} \mathrm{Y}_{12}$ receptor blocker development led to prasugrel and ticagrelor, which overcome the limitations of clopidogrel, such as delayed onset of action and high interindividual variability of antiplatelet response. ${ }^{10}$ Prasugrel is a third-generation thienopyridine with faster onset of action and less interindividual variability. It is more efficiently converted to an active metabolite than first- and second-generation thienopyridines. Thienopyridine derivatives exert their antiplatelet activity by irreversibly inhibiting the $\mathrm{P}_{2} \mathrm{Y}_{12}$ receptor. By contrast, ticagrelor is a new chemical class with faster onset of action and consistent platelet inhibition that does not require hepatic metabolism for its activity and causes reversible inhi-

Received December 9, 2014; accepted December 10, 2014; released online January 7, 2015

Division of Cardiology, Heart Institute, Asan Medical Center, University of Ulsan, Seoul, Korea

Mailing address: Cheol Whan Lee, MD, Division of Cardiology, Heart Institute, Asan Medical Center, University of Ulsan, 88, Olympic-

ro 43-gil, Songpa-gu, Seoul 138-736, Korea. E-mail: cheolwlee@ amc.seoul.kr

ISSN-1346-9843 doi:10.1253/circj.CJ-14-1348

All rights are reserved to the Japanese Circulation Society. For permissions, please e-mail: cj@j-circ.or.jp 


\begin{tabular}{|c|c|c|c|c|c|c|c|}
\hline Trial & Patients & $\mathbf{n}$ & Comparison & $\begin{array}{l}\text { Follow-up } \\
\text { (months) }\end{array}$ & $\begin{array}{l}\text { Primary } \\
\text { endpoints }\end{array}$ & Results & $P$ value \\
\hline TASS & TIA, stroke & 3,069 & $\begin{array}{l}\text { Ticlopidine vs. } \\
\text { aspirin }\end{array}$ & 36 & Death/stroke & $\begin{array}{c}\text { RRR, } 12 \% \\
95 \% \mathrm{Cl}(-2,26)\end{array}$ & 0.048 \\
\hline AAASPS & Stroke & 1,470 & $\begin{array}{l}\text { Ticlopidine vs. } \\
\text { aspirin }\end{array}$ & 24 & $\begin{array}{l}\text { Vascular death/MI/ } \\
\text { stroke }\end{array}$ & $\begin{array}{c}\mathrm{HR}, 1.22 \\
95 \% \mathrm{Cl}(0.94,1.57)\end{array}$ & 0.12 \\
\hline STAMI & STEMI & 1,809 & $\begin{array}{l}\text { Ticlopidine vs. } \\
\text { aspirin }\end{array}$ & 6 & $\begin{array}{c}\text { Death/Ml/ } \\
\text { stroke/angina }\end{array}$ & $8.0 \%$ vs. $8.0 \%$ & 0.966 \\
\hline CAPRIE & $\begin{array}{c}\text { Post-MI, stroke, } \\
\text { PAD }\end{array}$ & 19,185 & $\begin{array}{l}\text { Clopidogrel vs. } \\
\text { aspirin }\end{array}$ & 23 & $\begin{array}{l}\text { Vascular death/MI/ } \\
\text { stroke }\end{array}$ & $\begin{array}{c}\text { RRR, } 8.7 \% \\
95 \% \mathrm{Cl}(0.3,16.5)\end{array}$ & 0.043 \\
\hline SOCRATES & TIA, stroke & 9,600 & $\begin{array}{l}\text { Ticagrelor vs. } \\
\text { aspirin }\end{array}$ & 3 & Death/MI/stroke & $\begin{array}{l}\text { NCT01994720, } \\
\text { ongoing }\end{array}$ & \\
\hline
\end{tabular}

AAASPS, African American Antiplatelet Stroke Prevention Study; CAPRIE, Clopidogrel versus Aspirin in Patients at Risk of Ischemic Events; $\mathrm{Cl}$, confidence interval; HR, hazard ratio; MI, myocardial infarction; NA, not available; PAD, peripheral artery disease; RRR, relative risk reduction; STEMI, ST-elevation myocardial infarction; TASS, Ticlopidine Aspirin Stroke Study; TIA, transient ischemic attack.

bition of the $\mathrm{P} 2 \mathrm{Y}_{12}$ receptor.

\section{P2Y 12 Receptor Blockers vs. Aspirin}

Several randomized trials have investigated whether $\mathrm{P}_{2} \mathrm{Y}_{12}$ receptor blockers are safe and more effective than aspirin in patients with atherosclerotic cardiovascular disease (Table 1). ${ }^{11-14}$ In the Ticlopidine Aspirin Stroke Study (TASS), 3,069 patients with transient ischemic attack or mild stroke were randomized to take either ticlopidine $(500 \mathrm{mg} /$ day $)$ or aspirin $(1,300 \mathrm{mg} /$ day $) .{ }^{11}$ The 3 -year event rate for death from any causes or nonfatal stroke was significantly lower in the ticlopidine group compared with the aspirin group (17\% vs. $19 \%$, respectively, $\mathrm{P}=0.048)$. The rates of fatal and nonfatal stroke at year 3 were $10 \%$ for ticlopidine and $13 \%$ for aspirin $(\mathrm{P}=0.024)$; however, skin rash and gastrointestinal side effects with severe reversible neutropenia were more common in the ticlopidine group than in the aspirin group. These findings suggest that ticlopidine may be more effective than aspirin at preventing strokes in patients with recent ischemic stroke; however, in the African American Antiplatelet Stroke Prevention Study (AAASPS), in which 1,809 African American patients with noncardioembolic ischemic stroke were randomized to receive either ticlopidine $(500 \mathrm{mg} /$ day) or aspirin $(650 \mathrm{mg} /$ day $),{ }^{13}$ the 2 drugs were similar in terms of preventing recurrent strokes. The Clopidogrel versus Aspirin in Patients at Risk of Ischemic Events (CAPRIE) trial ${ }^{14}$ assessed the relative efficacy of clopidogrel $(75 \mathrm{mg}$ /day) and aspirin $(325 \mathrm{mg} /$ day) in reducing the risk of vascular death, MI or ischemic stroke (primary endpoints) in 19,185 patients with recent MI, recent ischemic stroke or symptomatic peripheral arterial disease. During a mean follow-up of 1.91 years, patients treated with clopidogrel had an annual 5.32\% risk of primary endpoint compared with $5.83 \%$ with aspirin (relativerisk reduction $8.7 \%$; $95 \%$ confidence interval $[\mathrm{CI}]$; 0.3-16.5; $\mathrm{P}=0.043)$. The overall safety profile of clopidogrel was similar to that of aspirin. These findings show that clopidogrel is more effective than aspirin at preventing recurrent vascular events in patients with atherosclerotic vascular disease. Taken together, the thienopyridine derivatives seem to be slightly but significantly better than aspirin at preventing serious vascular events in patients with atherosclerotic cardiovascular disease. A large-scale randomized trial comparing the efficacy and safety of ticagrelor and aspirin in patients with acute stroke or transient ischemic attack is ongoing (Table 1) to assess the relative benefits of ticagrelor over aspirin in this population.

\section{Antithrombotic Therapy for Stent Implantation}

Stent thrombosis has been a serious concern since the introduction of coronary artery stents in 1986. In early clinical experience, the rates of stent thrombosis were unacceptably high, approaching 20\%.15 Optimal stent deployment with adjunctive dual antiplatelet therapy (DAPT) resulted in a marked reduction in stent thrombosis and bleeding complications. ${ }^{16-18}$ In the Stent Anticoagulation Restenosis Study (STARS), ${ }^{17}$ 1,653 patients with successful stent placement were randomly assigned to 1 of 3 regimens: aspirin alone, aspirin and warfarin, or aspirin and ticlopidine. Compared with aspirin alone (3.6\%) and the combination of aspirin and warfarin $(2.7 \%)$, the combination of aspirin and ticlopidine $(0.5 \%)$ resulted in a lower rate of stent thrombosis within 30 days $(\mathrm{P}=0.001)$, demonstrating the superiority of aspirin and ticlopidine over aspirin and warfarin. DAPT with aspirin and clopidogrel for 1 month following bare-metal stent implantation was subsequently shown to be comparably effective and safer than aspirin and ticlopidine for the prevention of stent thrombosis, ${ }^{18}$ becoming the standard of care after coronary stent implantation.

\section{DAPT After Drug-Eluting Stents (DES) Implantation}

DES have dramatically reduced the rate of restenosis and become the mainstream device for percutaneous coronary intervention (PCI); however, late stent thrombosis remains an important limitation of these devices, ${ }^{19}$ leading to the recommendation of DAPT with aspirin and clopidogrel for at least 6-12 months after placement. ${ }^{20,21}$ These recommendations were largely based on retrospective analyses with conflicting results, ${ }^{22-24}$ requiring adequately powered randomized controlled trials. Fortunately, several randomized controlled trials have been performed to determine the optimal duration of DAPT after DES implantation (Table 2). ${ }^{25-38}$

\section{DAPT for 12 Months}

The benefit of DAPT beyond a 12-month period after PCI with DES was first tested in 2,701 patients who were free of major adverse cardiovascular events and major bleeding for at least 12 months after implantation. ${ }^{25}$ The cumulative risk of death from cardiac causes or MI at 24 months was $1.8 \%$ with DAPT, compared with $1.2 \%$ with aspirin monotherapy (hazard ratio [HR], $1.65 ; 95 \% \mathrm{CI}: 0.80-3.36 ; \mathrm{P}=0.17)$. No difference in the risk of bleeding complications was observed be- 


\begin{tabular}{|c|c|c|c|c|c|c|}
\hline Trial & $\begin{array}{l}\text { No. of } \\
\text { patients }\end{array}$ & Stent type & Duration & Primary endpoints & HR (95\% Cl) & $P$ value \\
\hline ZEST/REAL-LATE & 2,701 & PES, SES, E-ZES & 12 vs. $>12$ months & Cardiac death/MI & $0.61(0.30,1.25)$ & 0.17 \\
\hline DES LATE & 5,045 & Any DES & 12 vs. $>12$ months & Cardiac death/Ml/stroke & $0.94(0.66,1.35)$ & 0.75 \\
\hline ARTIC-interruption & 1,259 & Any DES & 12 vs. $>12$ months & $\begin{array}{l}\text { Death/Ml/stroke/ST/ } \\
\text { urgent revascularization }\end{array}$ & $1.17(0.68,2.03)$ & 0.58 \\
\hline \multirow[t]{2}{*}{ DAPT } & 9,961 & Any DES & 12 vs. 30 months & ST or & $3.45(2.08-5.88)$ & $<0.001$ \\
\hline & & & & Death/Ml/stroke & $1.41(1.18-1.69)$ & $<0.001$ \\
\hline PRODIGY & 2,013 & $\begin{array}{l}\text { BMS, PES, } \\
\text { E-ZES, EES }\end{array}$ & 6 vs. 24 months & Death/MI/stroke & $0.98(0.74,1.29)$ & 0.91 \\
\hline EXCELLENT & 1,443 & SES vs. EES & 6 vs. 12 months & $\begin{array}{l}\text { Cardiac death/Ml/ } \\
\text { target vessel revascularization }\end{array}$ & $1.14(0.70,1.86)$ & 0.60 \\
\hline SECURITY & 1,399 & New DES & 6 vs. 12 months & $\begin{array}{l}\text { Cardiac death/Ml/stroke/ST/ } \\
\text { BARC } 3,5 \text { bleeding at } 12 \text { months }\end{array}$ & NA & 0.469 \\
\hline ISAR-SAFE & 4,005 & Any DES & 6 vs. 12 months & $\begin{array}{l}\text { Death/MI/ST/stroke/ } \\
\text { TIMI major bleeding }\end{array}$ & NA & $\begin{array}{l}\text { Pnoninferiority } \\
<0.001\end{array}$ \\
\hline RESET & 2,117 & E-ZES vs. Any DES & 3 vs. 12 months & Cardiac death/MI/ST & NA & 0.84 \\
\hline OPTIMIZE & 3,119 & E-ZES & 3 vs. 12 months & Death/MI/stroke/major bleeding & $1.03(0.77,1.38)$ & 0.84 \\
\hline SMART-CHOICE & 5,100 & New DES & 3 vs. 12 months & $\begin{array}{c}\text { Death/Ml/stroke/ } \\
\text { BARC bleeding 2, 3, 4, } 5\end{array}$ & $\begin{array}{l}\text { NCT02079194, } \\
\text { ongoing }\end{array}$ & \\
\hline
\end{tabular}

BARC, Bleeding Academic Research Consortium; BMS, bare-metal stent; DAPT, dual antiplatelet therapy; DES, drug-eluting stent; EES, everolimus-eluting stent; E-ZES, Endeavor zotarolimus-eluting stent; New DES, Biomatrix ${ }^{\mathrm{TM}}$, EES (Xience ${ }^{\mathrm{TM}}$, Promus element ${ }^{\mathrm{TM}}$ ), Endeavor Resolute-ZES, NoboriTM; PES, paclitaxel-eluting stents; SES, sirolimus-eluting stent; ST, stent thrombosis; TIMI, thrombolysis in myocardial infarction. Other abbreviations as in Table 1.

tween the 2 groups. These findings were subsequently confirmed by an extended study ${ }^{26}$ showing that the use of DAPT for more than 12 months in stable patients with DES was not significantly more effective than aspirin monotherapy at preventing ischemic events. In the Assessment by a Double Randomization of a Conventional Antiplatelet Strategy versus a Monitoring-guided Strategy for Drug-Eluting Stent Implantation and of Treatment Interruption versus Continuation One Year after Stenting (ARCTIC)-Interruption trial, ${ }^{27} 1,259$ patients without contraindicated interruption of DAPT 12 months after DES implantation were randomly allocated to the continuation group or the interruption group. During a median follow-up of 17 months, no differences were observed in all-cause death, MI, stroke or transient ischemic attack, urgent coronary revascularization or stent thrombosis (HR, 0.85; 95\% CI: 0.49 1.47; $\mathrm{P}=0.58$ ); however, major or minor bleeding events were more common in the continuation group than in the interruption group (HR, 3.85; 95\% CI: $1.10-14.29 ; \mathrm{P}=0.04)$. In the DAPT study, ${ }^{28} 9,961$ patients who had been stable on DAPT for 12 months after DES implantation were randomly assigned to aspirin plus thienopyridine or aspirin plus placebo for 18 additional months. DAPT reduced the rates of stent thrombosis (HR, 0.29; 95\% CI: 0.17-0.48; $\mathrm{P}<0.001)$ and major adverse cardiovascular and cerebrovascular events (HR, 0.71; 95\% CI: $0.59-0.85$; $\mathrm{P}<0.001)$ compared with aspirin monotherapy. A $50 \%$ reduction in MI $55 \%$ not related to stent thrombosis) was also observed, showing that DAPT prevents MI in arteries beyond the stented lesions; however, the rate of all-cause death was higher in the DAPT group compared with the aspirin monotherapy group (HR, 1.36; 95\% CI: 1.00-1.85; $\mathrm{P}=0.05)$, and the rate of moderate or severe bleeding was also increased with DAPT $(2.5 \%$ vs. $1.6 \%, \mathrm{P}=0.001)$. Taken together, DAPT beyond 12 months after DES implantation may reduce both stent-related and other ischemic events beyond the stented region, but the benefits of DAPT are tempered by an increased risk of bleeding.

\section{DAPT for 6 Months}

In the Efficacy of Xience/Promus versus Cypher to Reduce Late Loss After Stenting (EXCELLENT) trial,29 1,443 patients who had received DES were randomized to receive 6 or 12 month DAPT. The rates of target vessel failure at 12 months were $4.8 \%$ in the 6-month DAPT group and $4.3 \%$ in the 12 month DAPT group ( $\mathrm{P}=0.001$ for noninferiority) with no difference in bleeding complications. Similarly, in the Prolonging Dual Antiplatelet Treatment after Grading Stent-Induced Intimal Hyperplasia Study (PRODIGY), ${ }^{30} 2,013$ patients were treated with 4 types of stents and then randomly allocated to receive 6 or 24 months of clopidogrel therapy in addition to aspirin. The rates of death of any cause, MI or cerebrovascular accident were not different between the 2 groups; however, DAPT for 24 months was associated with a significantly higher bleeding rate. These findings support the greater safety of 6-month DAPT compared with 12-month DAPT or longer after implantation of DES. In the Second-Generation DrugEluting Stent Implantation Followed by Six- versus TwelveMonth Dual Antiplatelet Therapy (SECURITY) trial, ${ }^{31} 1,399$ patients with newer-generation DES were randomized to receive 6-month or 12-month DAPT. No difference in efficacy or safety endpoints was observed between the 2 groups. In the Safety and Efficacy of Six-Month Dual Antiplatelet Therapy After Drug-Eluting Stenting (ISAR-SAFE) trial, ${ }^{32}$ 4,005 patients undergoing DES implantation were randomized to either 6- or 12-month DAPT. This trial was prematurely terminated because of recruitment issues and low event rates. The rate of primary major adverse cardiac events was similar between the 6- and 12-month DAPT groups (1.5\% vs. $1.6 \%$, $\mathrm{P}<0.001$ for noninferiority). TIMI major or minor bleeding events were similar between the 2 groups $(0.3 \%$ vs. $0.7 \%$, $\mathrm{P}=0.12$ ), whereas Bleeding Academic Research Consortium $\geq$ class 2 bleeding was lower in the 6-month DAPT group (1\% vs. $2 \%, \mathrm{P}=0.01)$ than in the 12 -month group. Taken together, 6 months of DAPT may be noninferior to 12 months of DAPT 


\begin{tabular}{|c|c|c|c|c|c|c|c|c|}
\hline Trial & Patients & $\mathbf{n}$ & $\begin{array}{c}\text { Anti-ischemic } \\
\text { therapy }\end{array}$ & Comparison & $\begin{array}{l}\text { Follow-up } \\
\text { (months) }\end{array}$ & $\begin{array}{l}\text { Primary } \\
\text { endpoints }\end{array}$ & Results & $P$ value \\
\hline \multirow[t]{2}{*}{ CURE } & \multirow[t]{2}{*}{ NSTE-ACS } & \multirow[t]{2}{*}{12,562} & \multirow{2}{*}{$\begin{array}{l}\mathrm{PCl}, \mathrm{CABG} \\
\text { medication }\end{array}$} & \multirow[t]{2}{*}{$A+C$ vs. $A$} & \multirow{2}{*}{$\begin{array}{c}3-12 \\
\text { (median, 9) }\end{array}$} & \multirow{2}{*}{$\begin{array}{l}\text { CV death/MI/ } \\
\text { stroke }\end{array}$} & $\mathrm{HR}, 0.80$ & \multirow[t]{2}{*}{$<0.001$} \\
\hline & & & & & & & $\begin{array}{c}95 \% \mathrm{Cl} \\
(0.72,0.90)\end{array}$ & \\
\hline \multirow[t]{2}{*}{ COMMIT/CCS-2 } & \multirow[t]{2}{*}{ Acute MI } & \multirow[t]{2}{*}{45,852} & \multirow[t]{2}{*}{ Medication } & \multirow[t]{2}{*}{$A+C$ vs. $A$} & \multirow[t]{2}{*}{1} & Death/MI/Stroke & $\begin{array}{l}\text { RRR, 9\% } \\
(3,14 \%)\end{array}$ & 0.002 \\
\hline & & & & & & Death & $\begin{array}{l}\text { RRR, } 7 \% \\
(1,13 \%)\end{array}$ & 0.03 \\
\hline CREDO & ACS, SA & 2,116 & $\mathrm{PCl}$ & $\begin{array}{c}A+C \text { for } 12 \text { months } \\
\text { vs. } A+C \text { for } 1 \text { month } \\
\rightarrow A\end{array}$ & 12 & $\begin{array}{l}\text { CV death/MI/ } \\
\text { stroke }\end{array}$ & $\begin{array}{l}\text { RRR, } 26.9 \% \\
(3.9,44.4 \%)\end{array}$ & 0.02 \\
\hline \multirow[t]{2}{*}{ TRITON-TIMI 38} & \multirow[t]{2}{*}{ ACS } & \multirow[t]{2}{*}{13,608} & \multirow[t]{2}{*}{$\mathrm{PCl}$} & \multirow{2}{*}{$A+P$ vs. $A+C$} & \multirow[t]{2}{*}{14.5} & \multirow{2}{*}{$\begin{array}{l}\mathrm{CV} \text { death/MI/ } \\
\text { stroke }\end{array}$} & $\mathrm{HR}, 0.81$ & \multirow[t]{2}{*}{$<0.001$} \\
\hline & & & & & & & $\begin{array}{c}95 \% \mathrm{Cl} \\
(0.73,0.90)\end{array}$ & \\
\hline \multirow[t]{2}{*}{ TRILOGY-ACS } & \multirow[t]{2}{*}{ NSTE-ACS } & \multirow[t]{2}{*}{7,243} & \multirow[t]{2}{*}{ Medication } & \multirow[t]{2}{*}{$A+P$ vs. $A+C$} & \multirow[t]{2}{*}{17} & \multirow{2}{*}{$\begin{array}{l}\mathrm{CV} \text { death/MI/ } \\
\text { stroke }\end{array}$} & $\mathrm{HR}, 0.91$ & \multirow[t]{2}{*}{0.211} \\
\hline & & & & & & & $\begin{array}{c}95 \% \mathrm{Cl} \\
(0.79,1.05)\end{array}$ & \\
\hline \multirow[t]{2}{*}{ PLATO } & \multirow[t]{2}{*}{ ACS } & \multirow[t]{2}{*}{18,624} & \multirow{2}{*}{$\begin{array}{l}\mathrm{PCl}, \mathrm{CABG} \\
\text { medication }\end{array}$} & \multirow[t]{2}{*}{$A+T$ vs. $A+C$} & $6-12$ & CV death/MI/ & HR, 0.84 & $<0.001$ \\
\hline & & & & & & stroke & $\begin{array}{c}95 \% \mathrm{Cl} \\
(0.77,0.92)\end{array}$ & \\
\hline CHARISMA & Post-MI, & 9,478 & Medication & $A+C$ vs. $A$ & 27.6 & CV death/MI/ & $\mathrm{HR}, 0.83$ & 0.01 \\
\hline subgroup & Stroke, PAD & & & & & stroke & $\begin{array}{c}95 \% \mathrm{Cl} \\
(0.72,0.96)\end{array}$ & \\
\hline PEGASUS & Post-MI & 21,000 & Medication & $\begin{array}{c}A+T(60 \mathrm{mg} \text { bid) vs. } \\
A+T \text { (90 mg bid) vs. } \\
\text { aspirin }\end{array}$ & $12-44$ & $\begin{array}{l}\text { CV death/MI/ } \\
\text { stroke }\end{array}$ & $\begin{array}{c}\text { NCT01225562, } \\
\text { ongoing }\end{array}$ & \\
\hline SMART-DATE & ACS & 3,000 & $\mathrm{PCl}$ & $\begin{array}{c}A+C \text { for } 6 \text { months } \\
\rightarrow A \text { vs. } A+C \text { for } \\
12 \text { months }\end{array}$ & $6-18$ & $\begin{array}{l}\text { Death/MI/stroke } \\
\text { ST/BARC } 3,4,5\end{array}$ & $\begin{array}{l}\text { NCT01701453, } \\
\text { ongoing }\end{array}$ & \\
\hline TALOS-AMI & Acute MI & 3,288 & $\mathrm{PCl}$ & $\begin{array}{l}A+T \text { for } 1 \text { month } \\
\rightarrow A+T \text { vs. } A+C\end{array}$ & 12 & $\begin{array}{c}\text { CV death/MI/ } \\
\text { stroke/BARC } \\
\text { bleeding } 2,3,5\end{array}$ & $\begin{array}{l}\text { NCT02018055, } \\
\text { ongoing }\end{array}$ & \\
\hline ISAR-REACTS5 & ACS & 4,000 & $\mathrm{PCl}$ & $A+T$ vs. $A+P$ & 12 & Death/MI/stroke & $\begin{array}{l}\text { NCT01944800, } \\
\text { ongoing }\end{array}$ & \\
\hline GLOBAL-LEADES & STEMI & 16,000 & $\mathrm{PCl}$ & $\begin{array}{l}A+T \text { for } 1 \text { month } \\
\rightarrow T \text { vs. } A+C \text { for } \\
12 \text { months } \rightarrow A\end{array}$ & 24 & Death/MI & $\begin{array}{l}\text { NCT01813435, } \\
\text { ongoing }\end{array}$ & \\
\hline
\end{tabular}

A, aspirin; ACS, acute coronary syndrome; C, clopidogrel; CABG, coronary artery bypass graft surgery; CV, cardiovascular; NSTE, non-STelevation; $\mathrm{P}$, prasugrel; $\mathrm{PCl}$, percutaneous coronary intervention; $\mathrm{SA}$, stable angina; $\mathrm{T}$, ticagrelor. Other abbreviations as in Tables 1,2.

in patients undergoing DES implantation, with a trend toward lower bleeding.

\section{DAPT for 3 Months}

DES technology has rapidly advanced over the past decade, and late stent thrombosis may be less of a clinical issue with newer-generation DES than with older devices. ${ }^{34}$ Furthermore, stent thrombosis mostly occurs within 3 months after DES implantation and rarely continues to occur thereafter. ${ }^{35}$ Previous DES are no longer used in routine clinical practice, and a growing body of evidence suggests that 3 months of DAPT may be safe in stable patients treated with newer-generation DES. ${ }^{36,37}$ Recently, the Optimized Duration of Clopidogrel Therapy Following Treatment with the Zotarolimus-Eluting Stent in Real-World Clinical Practice (OPTIMIZE) trial also showed that 3 months of DAPT after Endeavor zotarolimuseluting stent implantation was not inferior to 12 months of DAPT for net adverse clinical and cerebral events, without significantly increasing the risk of stent thrombosis. ${ }^{38}$ The 3-month DAPT regimen after newer-generation DES implantation may be considered in patients who are at low risk for stent thrombosis but at high risk for bleeding; however, both stented and non-stented lesions are involved in future coronary events, requiring a comprehensive approach.

\section{DAPT in Acute Coronary Syndrome (ACS)}

Plaque rupture and subsequent thrombus formation are the major disease mechanisms in ACS. Platelets initiate the formation of a thrombus at the plaque rupture site, and then the clotting cascade is activated as the thrombus matures. NonST-elevation ACS (NSTE-ACS) is usually caused by incomplete coronary occlusion by thrombi, and ST-elevation MI by complete occlusion. The central role of platelets in the development of ACS was demonstrated by several randomized studies showing the unequivocal clinical benefit of antiplatelet therapy. ${ }^{39-47}$ Current guidelines recommend DAPT for at least 12 months in all ACS patients, regardless of initial treatment strategy, if not contraindicated. ${ }^{48,49}$

\section{Previous DAPT in ACS}

The Clopidogrel in Unstable Angina to Prevent Recurrent Events (CURE) trial ${ }^{39}$ compared the efficacy and safety of longterm DAPT to that of aspirin alone in 12,562 patients with 
NSTE-ACS (Table 3). Patients who had presented within $24 \mathrm{~h}$ after the onset of symptoms were randomized to receive clopidogrel ( $300 \mathrm{mg}$ immediately followed by $75 \mathrm{mg}$ once daily) or placebo in addition to aspirin for 3-12 months. The primary endpoint of death from cardiovascular causes, nonfatal MI or stroke occurred in $9.3 \%$ of the patients in the DAPT group and $11.4 \%$ of the patients in the aspirin group (relative risk, $0.80 ; 95 \%$ CI: $0.72-0.90 ; \mathrm{P}<0.001)$. The rate of major bleeding was significantly higher in the DAPT group than in the aspirin group $(3.7 \%$ vs. $2.7 \%$; relative risk, $1.38 ; \mathrm{P}=0.001)$, but the rate of life-threatening bleeding or hemorrhagic stroke was similar between the 2 groups. This study demonstrated the benefit of 12-month DAPT in patients with NSTE-ACS, providing a background for recommending DAPT to ACS patients. In this trial, however, most patients (79\%) were treated with medication, and only $21 \%$ of the patients underwent PCI. The Clopidogrel for the Reduction of Events During Observation (CREDO) trial $^{40}$ investigated the benefit of 12 -month DAPT vs. 1-month DAPT after PCI in 2,116 patients with ACS (67.2\%) or stable angina $(32.8 \%)$. The rate of death, MI or stroke at 12 months was significantly lower in the long-term DAPT group compared with the short-term DAPT group (relative reduction, $26.9 \%$; $95 \%$ CI: $3.9 \%-44.4 \%$; $\mathrm{P}=0.02$ ). The risk of major bleeding at 12 months increased, but not significantly $(8.8 \%$ vs. $6.7 \%$, respectively, $\mathrm{P}=0.07$ ). These findings are consistent with the evidence from the CURE trial, suggesting that 12month DAPT with aspirin plus clopidogrel significantly reduces the risk of recurrent ischemic events after PCI in patients with ACS.

\section{New DAPT in ACS}

Despite previous DAPT, patients with ACS still have high rates of recurrent major vascular events after the index event, requiring new approaches with more potent antiplatelet agents. Several randomized trials have been performed to compare the safety and efficacy of new DAPT (aspirin and new P2Y 12 receptor blockers) with previous DAPT (aspirin and clopidogrel) in patients with ACS. ${ }^{42-44}$

The Trial to Assess Improvement in Therapeutic Outcomes by Optimizing Platelet Inhibition with Prasugrel-Thrombolysis in Myocardial Infarction 38 (TRITON-TIMI 38) ${ }^{42}$ randomized 13,608 moderate- to high-risk ACS patients scheduled for PCI to receive prasugrel (60 mg loading dose and then $10 \mathrm{mg} /$ day) or clopidogrel (300 mg loading dose and then $75 \mathrm{mg} /$ day) for 6-15 months. The rate of cardiovascular death, MI or stroke was $9.9 \%$ in the prasugrel group and $12.1 \%$ in the clopidogrel group (HR, 0.81; 95\% CI: 0.73-0.90; $\mathrm{P}<0.001$ ). Major bleeding occurred in $2.4 \%$ of the patients receiving prasugrel and $1.8 \%$ of the patients receiving clopidogrel (HR, 1.32; 95\% CI: $1.03-1.68 ; \mathrm{P}=0.03)$. Likewise, the rate of life-threatening bleeding was greater in the prasugrel group than in the clopidogrel group ( $1.4 \%$ vs. $0.9 \%$, respectively, $\mathrm{P}=0.01$ ), especially in patients with a history of transient ischemic attack/stroke, body weight $<60 \mathrm{~kg}$ or age $>75$ years. Overall mortality did not differ between the 2 groups. In the Targeted Platelet Inhibition to Clarify the Optimal Strategy to Medically Manage Acute Coronary Syndromes (TRILOGY ACS) trial, ${ }^{43}$ 7,243 patients under the age of 75 years with NSTE-ACS who were medically managed without revascularization were randomized to receive prasugrel ( $10 \mathrm{mg}$ daily) vs. clopidogrel $(75 \mathrm{mg}$ daily). At a median follow-up of 17 months, no difference in safety and efficacy endpoints was observed between the 2 groups.

The Study of Platelet Inhibition and Patient Outcomes (PLATO) trial ${ }^{44}$ compared ticagrelor (180 mg loading dose and then $90 \mathrm{mg}$ twice/day) to clopidogrel (300-600 mg loading dose and then $75 \mathrm{mg} /$ day) for the prevention of cardiovascular events in 18,624 patients with ACS. At 12 months, the primary endpoint of death from vascular causes, MI or stroke occurred in $9.8 \%$ of the patients receiving ticagrelor compared with $11.7 \%$ of those receiving clopidogrel (HR, $0.84 ; 95 \% \mathrm{CI}$ : $0.77-0.92 ; \mathrm{P}<0.001)$. Death from any cause was also lower in the ticagrelor group compared with the clopidogrel group ( $4.5 \%$ vs. $5.9 \%$, respectively, $\mathrm{P}<0.001$ ). The rate of major bleeding was similar between the ticagrelor and clopidogrel groups ( $11.6 \%$ vs. $11.2 \%$, respectively, $\mathrm{P}=0.43$ ), but the rate of major bleeding not related to coronary artery bypass grafting was higher in the ticagrelor group ( $4.5 \%$ vs. $3.8 \%, \mathrm{P}=0.03)$. These findings demonstrate that new DAPT with aspirin and ticagrelor is superior to previous DAPT in preventing recurrent vascular events in a broad population of patients presenting with ACS.

\section{Residual Risk and Beyond 12 Months}

Patients with ACS remain at high risk of recurrent ischemic events despite evidence-based optimal therapy. The risk of cardiovascular death, MI or stroke is approximately $10 \%$ within 12 months after an index event, and thereafter 3-5\% annually. Longer-duration DAPT beyond 12 months may improve outcomes for ACS patients; this has been an active area of investigation.

In the Clopidogrel for High Atherothrombotic Risk and Ischemic Stabilization, Management and Avoidance (CHARISMA) subgroup study, ${ }^{45} 9,478$ patients with prior MI, stroke or peripheral artery disease were randomized to receive either previous DAPT (aspirin and clopidogrel) or aspirin for 27.6 months. The rate of cardiovascular death, MI or stroke was significantly lower in the DAPT group than in the aspirin group (HR, 0.83; 95\% CI: 0.72-0.96; $\mathrm{P}=0.01$ ). Severe bleeding was not different between the 2 groups, but moderate bleeding was significantly higher in the DAPT group (HR, 1.60; 95\% CI: 1.16-2.20; $\mathrm{P}=0.004)$. These findings suggest that patients with prior MI may benefit from long-term DAPT beyond 12 months. In the Prevention of Thrombotic Events With Ticagrelor Compared to Placebo on a Background of Acetyl Salicylic Acid Therapy in Patients With History of Myocardial Infarction (PEGASUS) trial, approximately 21,000 patients with a history of spontaneous MI within 1 to 3 years and risk factors were randomized to ticagrelor ( $90 \mathrm{mg}$ twice daily), ticagrelor (60 mg twice daily) or matching placebo, all with low-dose aspirin $(75-150 \mathrm{mg} /$ day $)$. The primary endpoint is a composite of cardiovascular death, MI or stroke. The results will be available in the first quarter of 2015, providing useful information about the risks and benefits of long-term DAPT beyond 12 months in high-risk patients.

\section{Unresolved Issues}

\section{Bleeding Complications}

There is a significant association between the use of potent antiplatelet agents and excessive bleeding. The risk of major bleeding increases by $20-60 \%$ with the potency of antiplatelet therapy (Figure 1). ${ }^{39,42-45,50}$ DAPT duration also correlates with the risk of bleeding, limiting the benefits of long-term therapy. In general, prognosis in patients with CAD depends on clinical risk factors, left ventricular function and severity of disease $;{ }^{51}$ however, accurate models are not available to offer detailed guidance on the duration of DAPT for each individual patient.

Approximately $5 \%$ of the patients undergoing PCI are on 


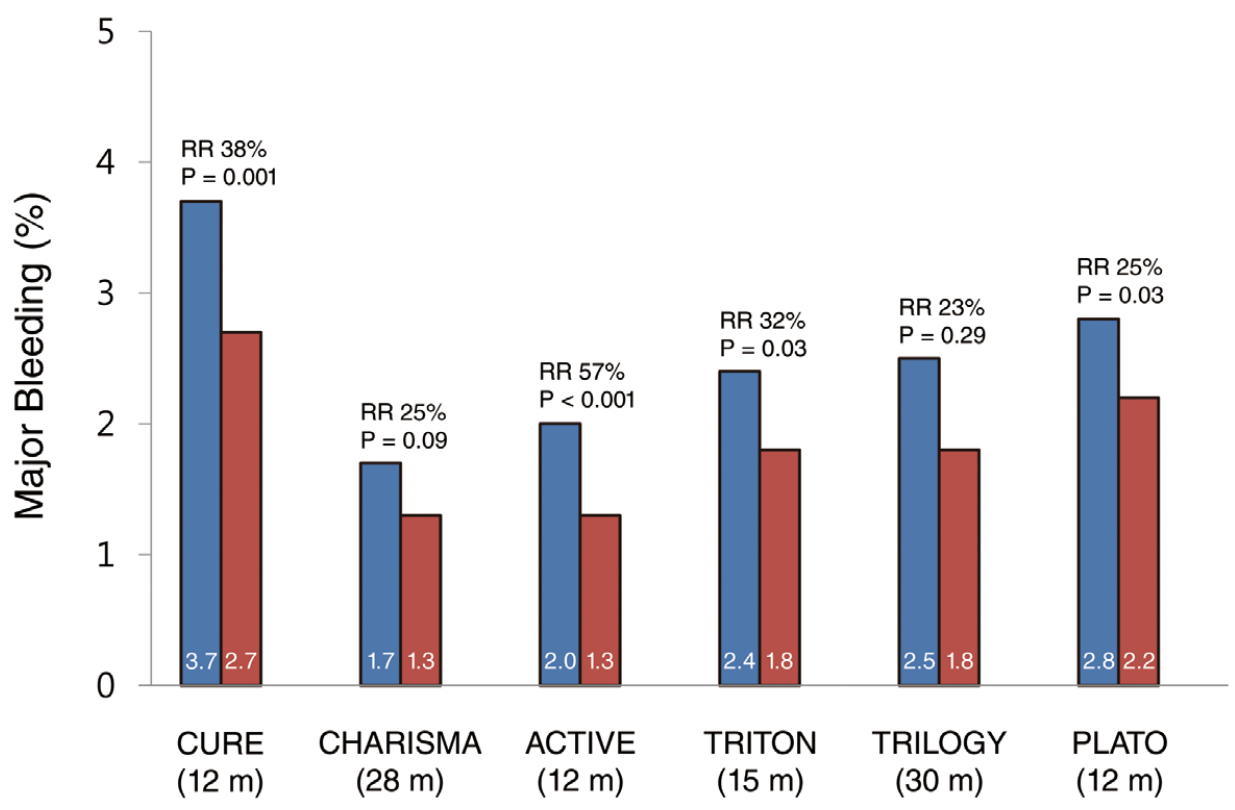

Figure 1. Incidence of major bleeding in large-scale randomized clinical trials comparing antiplatelet therapies (aspirin+clopidogrel vs. aspirin in the CURE, CHARISMA and ACTIVE trials; aspirin+prasugrel vs. aspirin+clopidogrel in the TRITON-TIMI38 and TRILOGY trials; aspirin+ticagrelor vs. aspirin+clopidogrel in the PLATO trial). Major bleeding events in the TRITON-TIMI 38 TRILOGY and PLATO trials were non-CABG-related TIMI major bleeding. Parentheses denote follow-up duration after randomization. CABG, coronary artery bypass graft surgery; TIMI, Thrombolysis in Myocardial Infarction; m, months; RR, relative risk.

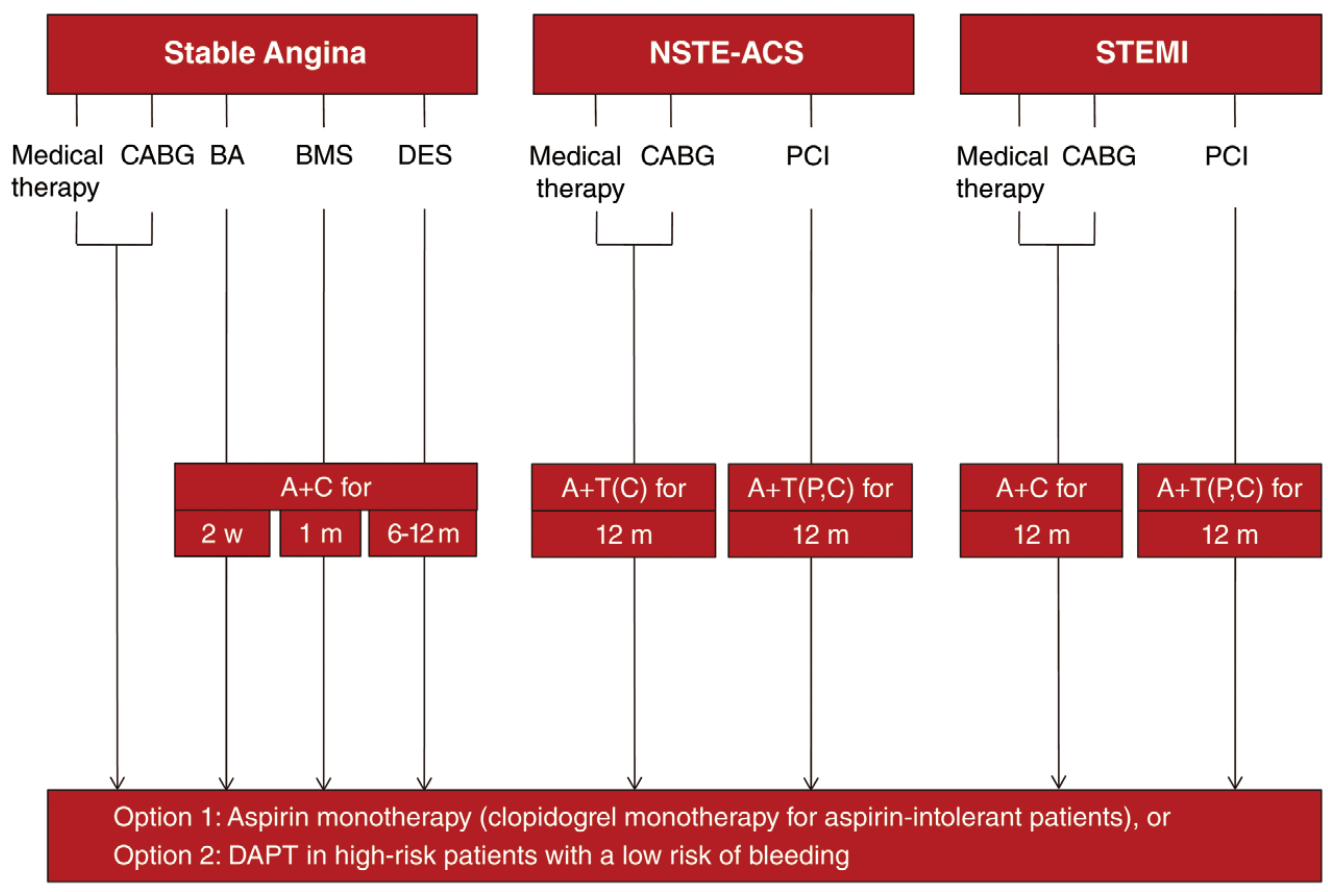

Figure 2. Schematic illustration of antiplatelet therapies for patients with coronary artery disease. A, aspirin; BA, balloon angioplasty; BMS, bare-metal stent; C, clopidogrel; CABG, coronary artery bypass graft surgery; DES, drug-eluting stent; $m$, months; NSTE-ACS, non-ST-elevation acute coronary syndrome; P, prasugrel; PCI, percutaneous coronary intervention; STEMI, ST-elevation myocardial infarction; T, ticagrelor; w, weeks. 
oral anticoagulants for nonvalvular atrial fibrillation. These patients should receive DAPT for 1 month after implantation of bare-metal stents, and for 6-12 months after implantation of DES. Conventional triple therapy with aspirin, clopidogrel and warfarin remarkably increases the risk of major bleeding. ${ }^{52}$ In this clinical setting, antithrombotic regimens including new oral anticoagulants are now under investigation to reduce the bleeding risk.

\section{Ethnic Differences}

The response to DAPT may vary with ethnicity. East Asian patients, despite a higher prevalence of clopidogrel resistance, seem to have a lower rate of ischemic events after DES implantation than Western patients, suggesting ethnic differences in the response to DAPT. ${ }^{53}$ The maintenance dose of P2 $\mathrm{Y}_{12}$ receptor blockers was determined from clinical trials conducted mostly in Caucasian populations. East Asians may require a lower dose of $\mathrm{P}_{2} \mathrm{Y}_{12}$ receptor blockers for similar protection from ischemic events. Further studies may be needed to clarify these issues.

\section{Bioresorbable Vascular Scaffold}

Bioresorbable vascular scaffolds represent an emerging approach to the percutaneous treatment of $\mathrm{CAD}$, providing transient vessel support and drug delivery to the vessel wall. ${ }^{54}$ Despite the potential advantages of this approach, concerns have been raised about the risk of stent thrombosis because of thick strut stents and incomplete stent apposition. The optimal DAPT regimens after implantation of bioresorbable vascular scaffolds remain to be determined.

\section{Summary}

DAPT is recommended for at least 6-12 months in patients with stable CAD undergoing DES placement, and for at least 12 months in all patients with ACS unless contraindicated (Figure 2). Prolonged DAPT beyond 12 months may be considered in patients at high risk for ischemic events. However, the benefits of long-term DAPT need to be balanced with the risks of bleeding, and therapy should be individualized for each patient.

\section{Acknowledgment}

This study was supported by a grant (2014-217) from the Asan Institute for Life Sciences, Seoul, Korea.

\section{References}

1. Antiplatelet Trialists' Collaboration. Collaborative overview of randomised trials of antiplatelet therapy. I: Prevention of death, myocardial infarction, and stroke by prolonged antiplatelet therapy in various categories of patients. BMJ 1994; 308: 81-106.

2. Antithrombotic Trialists' Collaboration. Collaborative meta-analysis of randomised trials of antiplatelet therapy for prevention of death, myocardial infarction, and stroke in high risk patients. BMJ 2002; 324: $71-86$.

3. Vane JR. Inhibition of prostaglandin synthesis as a mechanism of action for aspirin-like drugs. Nat New Biol 1971; 231: 232-235.

4. A randomized, controlled trial of aspirin in persons recovered from myocardial infarction. JAMA 1980; 243: 661-669.

5. ISIS-2 (Second International Study of Infarct Survival) Collaborative Group. Randomised trial of intravenous streptokinase, oral aspirin, both, or neither among 17,187 cases of suspected acute myocardial infarction: ISIS-2. Lancet 1988; 2: 349-360.

6. Jackson EA, Sivasubramian R, Spencer FA, Yarzebski J, Lessard D, Gore JM, et al. Changes over time in the use of aspirin in patients hospitalized with acute myocardial infarction (1975 to 1997): A population-based perspective. Am Heart J 2002; 144: 259-268.

7. Paikin JS, Eikelboom JW. Cardiology patient page: Aspirin. Circula- tion 2012; 125: e439-e442, doi:10.1161/CIRCULATIONAHA. 111.046243

8. Dorsam RT, Kunapuli SP. Central role of the P2Y12 receptor in platelet activation. J Clin Invest 2004; 113: 340-345.

9. Quinn MJ, Fitzgerald DJ. Ticlopidine and clopidogrel. Circulation 1999; 100: $1667-1672$.

10. Cattaneo M. New P2Y(12) inhibitors. Circulation 2010; 121: $171-$ 179.

11. Hass WK, Easton JD, Adams HP Jr, Pryse-Phillips W, Molony BA, Anderson S, et al. A randomized trial comparing ticlopidine hydrochloride with aspirin for the prevention of stroke in high-risk patients: Ticlopidine Aspirin Stroke Study Group. N Engl J Med 1989; 321: $501-507$.

12. Scrutinio D, Cimminiello C, Marubini E, Pitzalis MV, Di Biase M, Rizzon P. Ticlopidine versus aspirin after myocardial infarction (STAMI) trial. J Am Coll Cardiol 2001; 37: 1259-1265.

13. Gorelick PB, Richardson D, Kelly M, Ruland S, Hung E, Harris Y, et al; African American Antiplatelet Stroke Prevention Study Investigators. Aspirin and ticlopidine for prevention of recurrent stroke in black patients: A randomized trial. JAMA 2003; 289: 2947-2957.

14. CAPRIE Steering Committee. A randomised, blinded, trial of clopidogrel versus aspirin in patients at risk of ischaemic events (CAPRIE). Lancet 1996; 348: 1329-1339.

15. Serruys PW, Strauss BH, Beatt KJ, Bertrand ME, Puel J, Rickards $\mathrm{AF}$, et al. Angiographic follow-up after placement of a self-expanding coronary-artery stent. $N$ Engl J Med 1991; 321: 13-17.

16. Colombo A, Hall P, Nakamura S, Almagor Y, Maiello L, Martini G, et al. Intracoronary stenting without anticoagulation accomplished with intravascular ultrasound guidance. Circulation 1995; 91: 16761688.

17. Leon MB, Baim DS, Popma JJ, Gordon PC, Cutlip DE, Ho KK, et al. A clinical trial comparing three antithrombotic-drug regimens after coronary-artery stenting: Stent Anticoagulation Restenosis Study Investigators. N Engl J Med 1998; 339: 1665-1671.

18. Moussa I, Oetgen M, Roubin G, Colombo A, Wang X, Iyer S, et al. Effectiveness of clopidogrel and aspirin versus ticlopidine and aspirin in preventing stent thrombosis after coronary stent implantation. Circulation 1999; 99: 2364-2366.

19. Daemen J, Wenaweser P, Tsuchida K, Abrecht L, Vaina S, Morger $\mathrm{C}$, et al. Early and late coronary stent thrombosis of sirolimus-eluting and paclitaxel-eluting stents in routine clinical practice: Data from a large two-institutional cohort study. Lancet 2007; 369: 667-678.

20. King SB 3rd, Smith SC Jr, Hirshfeld JW Jr, Jacobs AK, Morrison DA, Williams DO, et al. 2007 Focused Update of the ACC/AHA/SCAI 2005 Guideline Update for Percutaneous Coronary Intervention: A report of the American College of Cardiology/American Heart Association Task Force on Practice Guidelines. Circulation 2008; 117: 261-295.

21. Wijns W, Kolh P, Danchin N, Di Mario C, Falk V, Folliguet T, et al. Guidelines on myocardial revascularization: The task force on myocardial revascularization of the European Society of Cardiology (ESC) and the European Association for Cardio-Thoracic Surgery (EACTS). Eur Heart J 2010; 31: 2501-2555.

22. Iakovou I, Schmidt T, Bonizzoni E, Ge L, Sangiorgi GM, Stankovic $\mathrm{G}$, et al. Incidence, predictors, and outcome of thrombosis after successful implantation of drug-eluting stents. JAMA 2005; 293: $2126-$ 2130.

23. Eisenstein EL, Anstrom KJ, Kong DF, Shaw LK, Tuttle RH, Mark DB, et al. Clopidogrel use and long-term clinical outcomes after drug-eluting stent implantation. JAMA 2007; 297: 159-168.

24. Schulz S, Schuster T, Mehilli J, Byrne RA, Ellert J, Massberg S, et al. Stent thrombosis after drug-eluting stent implantation: Incidence, timing, and relation to discontinuation of clopidogrel therapy over a 4-year period. Eur Heart J 2009; 30: 2714-2721.

25. Park SJ, Park DW, Kim YH, Kang SJ, Lee SW, Lee CW, et al. Duration of dual antiplatelet therapy after implantation of drug-eluting stents. N Engl J Med 2010; 362: 1374-1382.

26. Lee CW, Ahn JM, Park DW, Kang SJ, Lee SW, Kim YH, et al. Optimal duration of dual antiplatelet therapy after drug-eluting stent implantation: A randomized, controlled trial. Circulation 2014; 129: 304-312.

27. Collet JP, Silvain J, Barthélémy O, Rangé G, Cayla G, Van Belle E, et al; for the ARCTIC investigators. Dual-antiplatelet treatment beyond 1 year after drug-eluting stent implantation (ARCTIC-Interruption): A randomised trial. Lancet 2014; 384: 1577-1585.

28. Mauri L, Kereiakes DJ, Yeh RW, Driscoll-Shempp P, Cutlip DE, Steg PG, et al. Twelve or 30 months of dual antiplatelet therapy after drug-eluting stents. N Engl J Med 2014; 371: 2155-2166.

29. Gwon HC, Hahn JY, Park KW, Song YB, Chae IH, Lim DS, et al. Six-month versus 12 -month dual antiplatelet therapy after implanta- 
tion of drug-eluting stents: The efficacy of xience/promus versus cypher to reduce late loss after stenting (EXCELLENT) randomized, multicenter study. Circulation 2012; 125: 505-513.

30. Valgimigli M, Campo G, Monti M, Vranckx P, Percoco G, Tumscitz $\mathrm{C}$, et al. Short- versus long-term duration of dual-antiplatelet therapy after coronary stenting: A randomized multicenter trial. Circulation 2012; 125: 2015-2026.

31. Colombo A, Chieffo A, Frasheri A, Garbo R, Masotti M, Salvatella $\mathrm{N}$, et al. Second generation drug-eluting stents implantation followed by six- versus twelve-month dual antiplatelet therapy: The SECURITY randomized clinical trial. J Am Coll Cardiol 2014; 64: 2086-2097.

32. Schulz-Schüpke S, Mehilli J, Laugwitz KL, Neumann FJ, Berg JM, Adriaenssens T, et al. Six versus twelve months of clopidogrel therapy after drug-eluting stenting (ISAR-SAFE Trial). In: Proceedings of 2014 American Heart Association Scientific Sessions.

33. Kim BK, Hong MK, Shin DH, Nam CM, Kim JS, Ko YG, et al. A new strategy for discontinuation of dual antiplatelet therapy: The RESET trial (real safety and efficacy of 3-month dual antiplatelet therapy following Endeavor zotarolimus-eluting stent implantation). J Am Coll Cardiol 2012; 60: 1340-1348.

34. Palmerini T, Biondi-Zoccai G, Della Riva D, Stettler C, Sangiorgi D, D'Ascenzo F, et al. Stent thrombosis with drug-eluting and baremetal stents: Evidence from a comprehensive network meta-analysis. Lancet 2012; 379: 1393-1402.

35. Stone GW, Witzenbichler B, Weisz G, Rinaldi MJ, Neumann FJ, Metzger DC, et al. Platelet reactivity and clinical outcomes after coronary artery implantation of drug-eluting stents (ADAPT-DES): A prospective multicentre registry study. Lancet 2013; 382: $614-$ 623.

36. Naidu SS, Krucoff MW, Rutledge DR, Mao VW, Zhao W, Zheng Q, et al. Contemporary incidence and predictors of stent thrombosis and other major adverse cardiac events in the year after Xience V implantation: Results from the 8,061-patient Xience V United States study. JACC Cardiovasc Interv 2012; 5: 626-635.

37. Silber S, Kirtane AJ, Belardi JA, Liu M, Brar S, Rothman M, et al. Lack of association between dual antiplatelet therapy use and stent thrombosis between 1 and 12 months following resolute zotarolimus-eluting stent implantation. Eur Heart J 2014; 35: 1949-1956.

38. Feres F, Costa RA, Abizaid A, Leon MB, Marin-Neto JA, Botelho $\mathrm{RV}$, et al; OPTIMIZE Trial Investigators. Three vs. twelve months of dual antiplatelet therapy after zotarolimus-eluting stents: The OPTIMIZE randomized trial. JAMA 2013; 310: 2510-2522.

39. Yusuf S, Zhao F, Mehta SR, Chrolavicius S, Tognoni G, Fox KK; Clopidogrel in Unstable Angina to Prevent Recurrent Events Trial Investigators. Effects of clopidogrel in addition to aspirin in patients with acute coronary syndromes without ST-segment elevation. $N$ Engl J Med 2001; 345: 494-502.

40. Steinhubl SR, Berger PB, Mann JT 3rd, Fry ET, DeLago A, Wilmer $\mathrm{C}$, et al; CREDO Investigators. Clopidogrel for the Reduction of Events During Observation: Early and sustained dual oral antiplatelet therapy following percutaneous coronary intervention: A randomized controlled trial. JAMA 2002; 288: $2411-2420$.

41. COMMIT (ClOpidogrel and Metoprolol in Myocardial Infarction Trial) collaborative group. Addition of clopidogrel to aspirin in 45,852 patients with acute myocardial infarction: Randomised, placebo-controlled trial. Lancet 2005; 366: 1607-1621.

42. Wiviott SD, Braunwald E, McCabe CH, Montalescot G, Ruzyllo W, Gottlieb S, et al. Prasugrel versus clopidogrel in patients with acute coronary syndromes. N Engl J Med 2007; 357: 2001-2015.

43. Roe MT, Armstrong PW, Fox KA, White HD, Prabhakaran D, Goodman SG, et al; TRILOGY ACS Investigators. Prasugrel versus clopidogrel for acute coronary syndromes without revascularization. N Engl J Med 2012; 367: 1297-1309.

44. Wallentin L, Becker RC, Budaj A, Cannon CP, Emanuelsson H, Held C, et al; PLATO Investigators. Ticagrelor versus clopidogrel in patients with acute coronary syndromes. N Engl J Med 2009; 361: $1045-1057$.

45. Bhatt DL, Flather MD, Hacke W, Berger PB, Black HR, Boden WE, et al; CHARISMA Investigators. Patients with prior myocardial infarction, stroke, or symptomatic peripheral arterial disease in the CHARISMA trial. J Am Coll Cardiol 2007; 49: 1982-1988.

46. Bonaca MP, Bhatt DL, Braunwald E, Cohen M, Steg PG, Storey RF, et al. Design and rationale for the Prevention of Cardiovascular Events in Patients With Prior Heart Attack Using Ticagrelor Compared to Placebo on a Background of Aspirin-Thrombolysis in Myocardial Infarction 54 (PEGASUS-TIMI 54) trial. Am Heart J 2014; 167: $437-444$

47. Varenhorst C, Jensevik K, Jernberg T, Sundström A, Hasvold P, Held C, et al. Duration of dual antiplatelet treatment with clopidogrel and aspirin in patients with acute coronary syndrome. Eur Heart $J$ 2014; 35: 969-978.

48. Windecker S, Kolh P, Alfonso F, Collet JP, Cremer J, Falk V, et al. 2014 ESC/EACTS Guidelines on myocardial revascularization: The Task Force on Myocardial Revascularization of the European Society of Cardiology (ESC) and the European Association for CardioThoracic Surgery (EACTS)Developed with the special contribution of the European Association of Percutaneous Cardiovascular Interventions (EAPCI). Eur Heart J 2014; 35: 2541-2619.

49. Amsterdam EA, Wenger NK, Brindis RG, Casey DE Jr, Ganiats TG, Holmes DR Jr, et al. 2014 AHA/ACC Guideline for the management of patients with non-ST-elevation acute coronary syndromes: A report of the American College of Cardiology/American Heart Association task force on practice guidelines. J Am Coll Cardiol 2014; 64: e139-e228, doi:10.1016/j.jacc.2014.09.017.

50. Connolly SJ, Pogue J, Hart RG, Hohnloser SH, Pfeffer M, Chrolavicius S, et al; ACTIVE Investigators. Effect of clopidogrel added to aspirin in patients with atrial fibrillation. $N$ Engl $\mathrm{J} \mathrm{Med}$ 2009; 360: 2066-2078.

51. Park SJ, Lee CW. Coronary artery disease: Risk models for revascularization: The search continues. Nat Rev Cardiol 2012; 9: 316-318.

52. Sørensen R, Hansen ML, Abildstrom SZ, Hvelplund A, Andersson $\mathrm{C}$, Jørgensen $\mathrm{C}$, et al. Risk of bleeding in patients with acute myocardial infarction treated with different combinations of aspirin, clopidogrel, and vitamin K antagonists in Denmark: A retrospective analysis of nationwide registry data. Lancet 2009; 374: $1967-1974$.

53. Levine GN, Jeong YH, Goto S, Anderson JL, Huo Y, Mega JL, et al. Expert consensus document: World Heart Federation expert consensus statement on antiplatelet therapy in East Asian patients with ACS or undergoing PCI. Nat Rev Cardiol 2014; 11: 597-606.

54. Serruys PW, Chevalier B, Dudek D, Cequier A, Carrié D, Iniguez A, et al. A bioresorbable everolimus-eluting scaffold versus a metallic everolimus-eluting stent for ischaemic heart disease caused by denovo native coronary artery lesions (ABSORB II): An interim 1-year analysis of clinical and procedural secondary outcomes from a randomised controlled trial. Lancet 2015; 385: 43-54. 